\title{
HLTF Gene
}

National Cancer Institute

\section{Source}

National Cancer Institute. HLTF Gene. NCI Thesaurus. Code C19882.

This gene is involved in chromatin remodeling and regulation of transcription. 